Sylwetki 



\title{
Tomasz Siewierski
}

Instytut Historii Nauki PAN

https://orcid.org/0000-0002-0059-3462

\section{Feliks Tych. Historyk (ocalały z) Zagłady}

\begin{abstract}
Streszczenie
Artykuł prezentuje biografię Feliksa Tycha, historyka, badacza dziejów ruchów lewicowych, wieloletniego pracownika Zakładu Historii Partii przy KC PZPR, Centralnego Archiwum KC PZPR, dyrektora Żydowskiego Instytut Historycznego. W tekście skoncentrowano się na nieznanych dotąd wątkach z życiorysu Tycha, dotyczących jego żydowskiego domu w Radomsku, oraz na uwięzieniu i ucieczce z tamtejszego getta w przededniu wielkiej akcji likwidacyjnej, a także okolicznościach przetrwania w okupowanej Warszawie. Następnie przedstawiono powojenne losy historyka, podejmując refleksję nad konsekwencjami wojennych przeżyć i ich wpływu na wybory dokonywane przez Tycha w życiu zawodowym.
\end{abstract}

\section{Słowa kluczowe}

Feliks Tych, Żydowski Instytut Historyczny, getto w Radomsku, pomoc Żydom, antysemityzm, historia historiografii, lewica

\begin{abstract}
This article presents the biography of Feliks Tych, historian, researcher of the left, a long-standing employee of the Party History Institute of the Party History Institute of the Central Committee of the Polish United Workers' Party, Central Archives of the the Central Committee of the Polish United Workers' Party, director of the Jewish Historical Institute. The text focuses on previously unknown threads of Tych's life, concerning his Jewish home in Radomsko, and of his imprisonment and escape from the ghetto in the town on the eve of the great liquidation operation, as well as the circumstances of his survival in occupied Warsaw. The post-war fate of the historian is subsequently discussed, reflecting on the consequences of war-time experiences and their impact on Tych's career choices.
\end{abstract}

\section{Key words}

Feliks Tych, Jewish Historical Institute, Radomsko ghetto, help to Jews, anti-Semitism, history of historiography, the left

W sześćdziesiątą piątą rocznicę wyzwolenia obozu zagłady Auschwitz-Birkenau, 27 stycznia 2010 r. w murach berlińskiego Bundestagu odbyła się coroczna ceremonia z okazji Dnia Pamięci o Ofiarach Holokaustu. Zebrani usłyszeli dwa przemówienia: prezydenta Izraela Szimona Peresa oraz profesora Feliksa Ty- 
cha. Organizatorzy wydarzenia poprosili Tycha o wystąpienie w dwóch rolach: nie tylko jako historyka Zagłady, lecz także jej świadka. Ta druga rola była może ważniejsza, ale dla Tycha wyjątkowo trudna. 0 swoim życiu przed 1942 r. nie mówił nawet najbliższym. Po raz pierwszy o żydowskim domu i doświadczeniach $\mathrm{z}$ radomszczańskiego getta opowiedział publicznie $\mathrm{w}$ wieku osiemdziesięciu lat, zmagając się z postępującą chorobą pamięci. Poza tym jednym świadectwem dysponujemy urywkami wspomnień, które - bardzo tłumione - czasami, fragmentami, z głębi wypływały w codziennych rozmowach.

Sięgając po powojenne dokumenty ${ }^{1}$ i biogramy ${ }^{2}$, znajdziemy informację, że Feliks Tych urodził się w Warszawie lub Kaliszu 31 lipca 1929 r. W rzeczywistości bohater niniejszego tekstu urodził się w Radomsku jako Fiszel Szpiro ${ }^{3}$. Kalisz był miastem rodzinnym Koszutskich, dzięki którym ocalał po aryjskiej stronie, ukrywając się w Warszawie od września 1942 r.

\section{Przypomnienia z Radomska}

Niewiele wiemy o jego rodzinnym domu ani o jego dzieciństwie. Był ostatnim z dziewięciorga dzieci Abrama Mojżesza i Estery Chai (z d. Szpichler) Szpirów. Był to tradycyjny dom żydowski. Nikt z członków rodziny nie miał bezpośrednich powiązań z przedwojennym ruchem komunistycznym. Tu jednak należy dodać, że o swoim pochodzeniu Feliks Tych nie tylko przez zdecydowaną większość życia nie mówił i unikał ujawniania swojego rodowego nazwiska. Zaraz po zakończeniu wojny chciał wrócić do nazwiska rodziców, ale od przybranej matki usłyszał wówczas: „synku, jeszcze nie teraz”4 Jak pokazały późniejsze wydarzenia, Wanda Koszutska wiedziała, co mówi.

Najstarszy z rodzeństwa Fiszela był Leon. Możemy zakładać, że był od niego około dwadzieścia lat starszy. Z informacji zawartej w jednej z ankiet po wojnie dowiadujemy się, że zajmował się handlem. Przed wojną zdążył założyć rodzinę. Doczekał się córki Miriam. Następny był Zygmunt. Pracował jako ślusarz w fabryce ojca. Kolejny brat nazywał się Jakub Hersz, urodził się w 1917 r. i najpewniej pracował jako robotnik, podobnie jak ostatni z braci, urodzony w roku 1921 Pinkus, który przed wojną przygotowywał się do zawodu ślusarza. Wiemy także, że zdążył ukończyć technikum. Z czterech sióstr najstarsza była Rena, urodzona

${ }^{1} \mathrm{~W}$ indeksie studenckim znajduje się informacja, że Feliks Tych urodził się w Kaliszu, na dyplomie ukończenia studiów jako miejsce urodzenia pojawia się Warszawa (Archiwum Uniwersytetu Warszawskiego [dalej AUW], Akta studenckie Feliksa Tycha, sygn. WHum. 13996).

${ }^{2}$ Zob. Tych Feliks [w:] Kto jest kim w Polsce. Informator biograficzny. Edycja 3, red. Lubomir Mackiewicz, Anna Żołna, Warszawa: Interpress, 1993; s. 759; Anna Landau-Czajka, Feliks Tych (31 VII 1929 - 17 II 2015), „Kwartalnik Historyczny” 2016, z. 3, s. 637; Piotr Kendziorek, Feliks Tych - szkic biograficzny in memoriam, „Kwartalnik Historii Żydów” 2015, z. 3, s. 553.

${ }^{3}$ Odpis skróconego aktu urodzenia wystawionego przez Urząd Stanu Cywilnego w Radomsku w posiadaniu rodziny; kopia w zbiorach autora.

${ }^{4}$ Rozmowa autora z Lucyną Berman-Tych. 
w 1914 r. Przeprowadziła się do Warszawy, gdzie studiowała architekturę. Tam poznała swojego przyszłego męża Wolfa Folmana. Mela, której daty urodzenia nie znamy, była ukochaną siostrą Fiszela. Z urywków wspomnień wiemy, że była blondynką, przed wojną wyszła za mąż (za Fuchsa, komunistę, co negatywnie wpłynęło na jej relacje z ojcem) i urodziła córkę, którą - tak jak starszy brat - nazwała Miriam. Była siostrą poświęcającą najmłodszemu bratu najwięcej uwagi i czułości, gdy ten w dzieciństwie cierpiał na astmę. W okresach choroby zostawała przy nim, głaskała go po plecach i przynosiła mu budyń śmietankowy. Nie wiemy nic o kolejnej siostrze, Marii, po mężu Wittenberg. Takie imię pojawia się w jednym z powojennych dokumentów. Najmłodsza siostra miała na imię Róża, urodziła się w $1923 \mathrm{r}^{5}$

Do Abrama Szpiry należała fabryka okuć metalowych. Nie było to wielkie przedsiębiorstwo. Zatrudniał on około 25 osób. Prosperował całkiem nieźle, dopóki nie nadszedł wielki kryzys gospodarczy, który zaczął się wkrótce po narodzeniu najmłodszego syna Fiszela. Bohater niniejszego tekstu nie zobaczył już umiarkowanego dobrobytu, lecz zapracowanych rodziców, zmagających się z problemami finansowymi. Wiele lat później Tych wspominał sytuację, gdy do domu wracała zapłakana najmłodsza siostra Róża, bo rodzice nie zapłacili czesnego za jej gimnazjum. Gdy w Polsce Ludowej pojawiły się w sprzedaży mandarynki i w domu rozchodził się ich zapach, Feliks wspominał ojca, który za każdym razem, gdy wracał z delegacji na Śląsk, miał w obu kieszeniach płaszcza po jednej mandarynce dla Fiszela i Róży, czyli dwójki najmłodszych dzieci. Świadczyło to m.in., że nie stać go było na więcej owoców. Mimo kiepskiej sytuacji materialnej Abram pozostawał człowiekiem bardzo religijnym i z niechęcią odnosił się do wszelkich przejawów komunizmu. Przekonali się o tym także Pinkus i Fiszel, gdy pewnego dnia dołączyli do strajkujących w fabryce ojca robotników. Śpiewanie wraz z nimi pieśni rewolucyjnych było formą rozrywki, Abram jednak nie był skłonny tolerować ich udziału w tym przedsięwzięciu właśnie ze względu na kontakt synów z nieodpowiednią ideologią ${ }^{6}$.

Rodzice nie poświęcali Fiszelowi wiele czasu. Jak już wspomniałem, był to niełatwy czas dla przedsiębiorców i Szpirowie koncentrowali się głównie na utrzymaniu licznej rodziny. Z tego względu decydujący udział w wychowaniu najmłodszego brata przypadł starszemu rodzeństwu. Fiszel dość szybko nauczył się czytać. Ponieważ w domu nie było książek, w wieku kilku lat zapisał się do miejscowej biblioteki OMTUR (Organizacji Młodzieży Towarzystwa Uniwersytetu Robotniczego). Jednorazowo mógł wypożyczyć dwie książki. Opracował więc system polegający na tym, że wypożyczał jedną książkę grubą, drugą cienką. Tę cienką czytał na schodach biblioteki, wymieniał na drugą grubą i wracał do domu. Nikt - ani bibliotekarki, ani starsze rodzeństwo - nie kierował wyborem lektur, czytał więc bardzo różne książki: od Henryka Sienkiewicza do Wandy

\footnotetext{
${ }^{5}$ Rozmowa autora z Lucyną Berman-Tych.

${ }^{6}$ Rozmowa autora z Lucyną Berman-Tych.
} 
Melcer. Pierwsze własne książki otrzymał od szwagra, Wolfa Folmana. Była to głównie literatura popularnonaukowa, np. modny wówczas Łowca mikrobów Paula de Kruifa. Jego drugą dziecięcą namiętnością było kino. Szczególnie lubił westerny z Tomem Mixem. W wieku sześciu lat Fiszel poszedł do szkoły. Odbyło się to poza wiedzą zajętych rodziców. Zapisał go brat Pinkus. Zdążył także poznać przedwojenną Warszawę. W związku z częstymi atakami astmy rodzice zdecydowali się wysłać go do stolicy, do Kliniki Chorób Dziecięcych. Po kilku dniach tam spędzonych wraz z siostrą Reną i jej mężem Wolfem Folmanem m.in. zwiedził zoo, a w nowo otwartym kinie Palladium obejrzał Królewnę Śnieżkę i siedmiu krasnoludów Walta Disneya ${ }^{7}$.

\section{Getto w Radomsku}

W grudniu 1939 r. rodzina Szpirów znalazła się w radomszczańskim get$\mathrm{cie}^{8}$. 0 tamtejszych warunkach życia Feliks Tych opowiedział w 2010 r., podczas przemówienia w Bundestagu w Dniu Pamięci o Holokauście9. W miejsce czteropokojowego mieszkania dziesięcioosobowa rodzina ${ }^{10}$ musiała pomieścić się w niewielkim, 12-metrowym pokoju na poddaszu drewnianego domku z toaletą na zewnątrz na obrzeżach getta. Mimo złych warunków życia w domu panowało przekonanie, że nie spotka już ich nic gorszego.

Mój racjonalistycznie myślący ojciec nie dopuszczał do siebie myśli, że eskalacja terroru i szykan może prowadzić do totalnej zagłady Żydów. Wydawało mu się to czymś niewyobrażalnym, bo zupełnie irracjonalnym, sprzecznym $\mathrm{z}$ interesami zaangażowanych $\mathrm{w}$ wojnę i potrzebujących siły roboczej Niemców. Moi rodzice mieli jeszcze w pamięci wolną od brutalności okupację niemiecką lat I wojny światowej. Wielokrotnie słyszałem z ust mojego Ojca słowa: „Hitler hin, Hitler her, ale Niemcy nie są narodem morderców”. Nigdy już się nie dowiem, co myślał w ostatnich chwilach swego życia, w Treblince ${ }^{11}$.

\footnotetext{
${ }^{7}$ Rozmowa autora z Lucyną Berman-Tych.

${ }^{8}$ Jedną z ostatnich naukowych publikacji Feliksa Tycha jest opracowany przez niego pamiętnik nastoletniej Miriam Chaszczewackiej, koleżanki jego siostry Róży. Rodzina Chaszczewackich była znana Fiszelowi. Zapiski Miriam są ważnym świadectwem dotyczącym radomszczańskiego getta. Zob. Pamiętnik Miriam Chaszczewackiej, oprac. Feliks Tych, „Zagłada Żydów. Studia i Materiały" 2013, nr 9, s. 427-469.

${ }^{9}$ Speech by Professor Feliks Tych [w:] Day of Remembrance for the Victims of National Socialism. Ceremony of Remembrance at the German Bundestag on 27 January 2010, s. 64-69.

${ }^{10}$ Rena mieszkała z rodziną w Warszawie. Pinkus po wzięciu udziału w obronie Warszawy trafił do Związku Radzieckiego. Mela z rodziną - mieszkająca przed wojną w Zawierciu - trafiła do getta w Będzinie, gdzie wszyscy ostatecznie zginęli.

${ }^{11}$ Bagaż [Rozmowa z Lucyną Berman-Tych] [w:] Przynoszę rzecz, przynoszę historię. Rozmowy z darczyńcami, red. Judyta Pawlak, Przemysław Kaniecki, Warszawa: Muzeum Historii Żydów Polskich Polin, 2016, s. 249.
} 
Ponad dwa lata Fiszel spędził na czytaniu. Na strychu domu znalazł osobliwą lekturę. Po polskich mieszkańcach gettowego mieszkania pozostały roczniki „Rycerza Niepokalanej” i „Małego Rycerzyka Niepokalanej”. Prasę tę przyszły historyk czytywał namiętnie. Jak się okazało, była to bardzo pomocna lektura, gdy wiele miesięcy później udało mu się wydostać z getta. 31 lipca 1942 r. przypadły trzynaste urodziny Fiszela. Przywiązany do tradycji żydowskiej Abram zorganizował synowi bar micwę. W warunkach getta ceremonia odbyła się $\mathrm{w}$ jakimś niewielkim pokoju zaadaptowanym na wnętrze synagogi. Dla religijnego ojca była wielkim przeżyciem, dla Fiszela oznaczała konieczność nauczenia się podstaw języka hebrajskiego. Jak pokazały kolejne tygodnie, była to ostatnia wspólna uroczystość rodziny Szpirów. Wkrótce po niej Fiszel wyjechał z Radomska. Stało się to we wrześniu 1942 r. w przededniu akcji likwidacyjnej w radomszczańskim getcie. Nie wiedziano, co ma się wydarzyć, coraz częściej jednak słyszano o planowanej Aktion, o której mówili między sobą Niemcy. „Podobnie jak większość osób w getcie moi rodzice przypuszczali, że oznacza to pogrom bądź masową łapankę ludzi celem skierowania ich do obozów pracy". Rodzice postanowili wysłać Fiszela do mieszkającej w Warszawie po aryjskiej stronie siostry, Reny Folman. Żegnając się z matką, nie miał podejrzeń, że już więcej nie zobaczy rodziców ani części rodzeństwa. Wyszedł z niewielkim bagażem, który przetrwał wojnę, a następnie z dbałością przechowywał go w domu. „On powiedział któregoś dnia o tej walizeczce, że na tym podwórku mama mu ją dała. I tam były zmiana bielizny i słoiczek smalcu gęsiego, bo wiedziała, że on go lubi"12. Walizeczka znajduje się obecnie w zbiorach Muzeum Historii Żydów Polskich Polin.

\section{Warszawa: po aryjskiej stronie}

Były pracownik fabryki Abrama Szpiry przetransportował Fiszela do Warszawy i zaprowadził do mieszkających na warszawskim Żoliborzu Reny i Wolfa Folmanów. Uciekli oni wcześniej z warszawskiego getta, gdzie zdążył urodzić się ich syn Rafał. Wolf, zakonspirowany jako Wacław Marciniak, pracował w Społecznym Przedsiębiorstwie Budowlanym i był asystentem Szymona Syrkusa. Początkowo Marciniak znajdował Fiszelowi miejsca krótkotrwałych kryjówek. Przez pracującą również w SPB Jadwigę Koszutską-Issat, która udzielała już pomocy dwójce żydowskich dzieci, rodzeństwu Irenie i Bogdanowi Wojdowskim, udało mu się znaleźć stałe schronienie ${ }^{13}$. Dzięki niej trafił do Wandy Koszutskiej (siostry Jadwigi). Później określał ją jako swoją przybraną mamę. Wanda wywodziła się z kaliskiej rodziny o szerokich i bliskich związkach z polskim ruchem lewicowym, także komunistycznym. Była jedną z trzech córek Bronisława Koszut-

${ }^{12}$ Ibidem, s. 249 .

${ }^{13}$ Feliks Tych, Wstęp [w:] Chawka Folman-Raban, Nie rozstałam się z nimi, Warszawa: ŻIH, 2000, s. 7; Koszutska-Issat Jadwiga Danuta [w:] Michał Grynberg, Księga sprawiedliwych, Warszawa: Wydawnictwo Naukowe PWN, 1993, s. 258. 
skiego, lekarza okulisty i społecznika, współpracownika Feliksa Dzierżyńskiego, przez pewien czas działacza Socjaldemokracji Królestwa Polskiego i Litwy ${ }^{14}$.

Warto też w tym miejscu, nieco na marginesie dodać, że wkrótce po Fiszelu $\mathrm{z}$ radomszczańskiego getta udało się zbiec także jego siostrze Róży. Ona również dostała się do Warszawy i udzielono jej schronienia. Od tej pory nazywała się Halina. Z polskimi papierami trafiła na roboty do Niemiec, z których ostatecznie uciekła wraz ze swoim narzeczonym i dostała się do jugosławiańskiej partyzant$\mathrm{ki}^{15}$. Przed likwidacją getta w Radomsku do Warszawy zbiegli także Jakub Hersz i Zygmunt.

Fiszel zamieszkał z Wandą Koszutską i jej rodziną w podwarszawskim Miedzeszynie. Tu, jako 13-letni chłopiec, przyszły historyk wymyślił sobie tożsamość - Feliks Tych. Do rodowego nazwiska już nigdy nie wrócił, także niechętnie je ujawniał. Nowe nazwisko wziął od barona von Tycha - negatywnej postaci z komiksowego pisemka dla dzieci, które akurat czytał ${ }^{16}$. Na nowe nazwisko Wolf Folman vel Wacław Marciniak ${ }^{17}$ zorganizował mu dokumenty. Feliks miał tzw. dobry wygląd, był blondynem o jasnoniebieskich oczach, dzięki czemu nie musiał żyć w absolutnym ukryciu, lecz - jak wspominał - całkiem swobodnie spacerował po Warszawie. Barbarze Engelking opowiadał: „Instynktownie uważałem, że jestem mniej zagrożony poza mieszkaniem, bo mieszkanie zawsze ktoś może zadenuncjować. Tak uważała zapewne - sądząc z tolerowania przez nią mojej niemal codziennej włóczęgi po mieście - moja przybrana matka. [...] To ona nauczyła mnie, że to, że żyję, jest normalne. Bo zaszczuci łatwiej ginęli. [...] Wolałem więc siedzieć w księgarni (szczególnie u Gebethnera i Wolffa na rogu ulic Zgoda i Sienkiewicza, z jej ogromną przestrzenią, dwoma poziomami i dość ciemnym wnętrzem, które też budziło większe poczucie bezpieczeństwa) i przeglądać książki, czy - wstyd powiedzieć - chodzić do kina, gdzie oglądałem, co popadło"18. Odwiedzał m.in. swojego starszego brata Jakuba Hersza, którego jako Józefa Gronkę ukrywał Janusz Durko, przyszły szef Tycha w Centralnym Archiwum Komitetu Centralnego Polskiej Zjednoczonej Partii Robotniczej, wieloletni dyrektor Muzeum Historycznego m.st. Warszawy. Wówczas jednak, podob-

${ }^{14}$ Jan Kancewicz, Koszutski Bronisław Romuald [w:] Słownik biograficzny działaczy polskiego ruchu robotniczego, red. nacz. Feliks Tych, t. 3, Warszawa: Muzeum Niepodległości w Warszawie oraz Książka i Wiedza, 1992, s. 323-324.

${ }^{15}$ Lucyna Tychowa, Andrzej Romanowski, Tak, jestem córkq Jakuba Bermana, Kraków: Universitas, 2016, s. 89.

${ }^{16}$ Ibidem, s. 86.

${ }^{17}$ Folman zginął wkrótce, próbując, wraz z przyjacielem Leonem Rytowskim (również uciekinierem z warszawskiego getta, aktorem), dostać się GL-owskiej partyzantki na Kielecczyźnie, do oddziału dowodzonego przez Ignacego Robb-Narbutta. Według relacji Janusza Durki, Folmana trafiła niemiecka kula podczas próby ucieczki przed Niemcami otaczającymi wieś, w której się zatrzymali. Por. Rozmowa z Januszem Durko z kolekcji historii mówionej Muzeum Historii Żydów Polskich Polin, 2009 r.

${ }^{18}$ Rozmowa z prof. Feliksem Tychem, „Zagłada Żydów. Studia i Materiały” 2006, nr 2, s. 340. 
nie jak Jadwiga Koszutska-Issat i wielu innych Sprawiedliwych, pracował w SPB. Durko udzielał pomocy nie tylko Józefowi, lecz także wspomnianym już Renie i Wolfowi Folmanom, Aleksandrowi Węgierce, Leonowi Rytowskiemu, Aleksandrowi Dyszce-Wolskiemu i innym ${ }^{19}$. Warto dodać, że Jakub Hersz przybył do Warszawy już po likwidacji radomszczańskiego getta. Jako robotnik w fabryce, która wcześniej należała do jego ojca, sypiał na jej terenie, poza gettem. Jak zrelacjonował to Januszowi Durce, pewnego dnia okazało się, że rodziców i rodzeństwa już tam nie ma ${ }^{20}$. Natomiast Józefowi Gronce udało się przeżyć wojnę. Początkowo zamieszkiwał u Durki w jego mieszkaniu przy ul. Krechowieckiej na Żoliborzu, a następnie - po nakryciu go przez szmalcowników w łaźni publicznej przy ul. Suzina - przyszły dyrektor Muzeum Historycznego m.st. Warszawy znalazł mu lokum przy ul. Senatorskiej. Tam odwiedzał go Feliks i zapewne przy tej okazji zostało zrobione poniższe zdjęcie, najstarsza fotografia Feliksa Tycha, jaką dysponujemy.

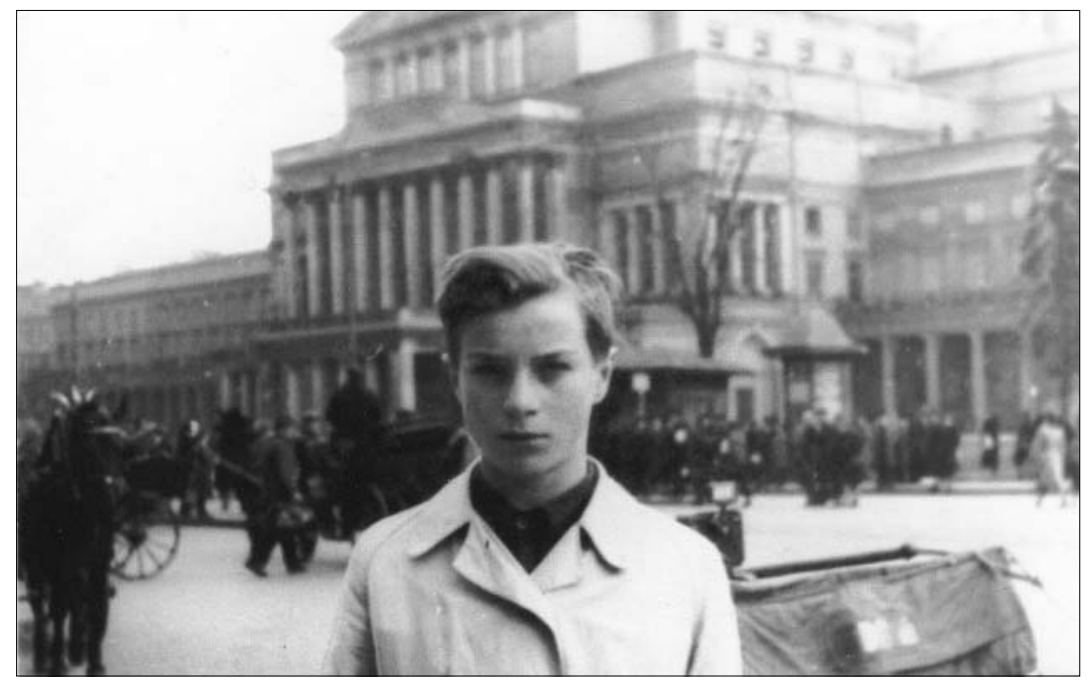

Feliks Tych na pl. Teatralnym w Warszawie, 1942 lub 1943 r. (fot. ze zbiorów rodzinnych)

Niestety, nie wiemy nic na temat kontaktów Feliksa z drugim ukrywającym się w Warszawie bratem, Zygmuntem. Nie zachowała się żadna relacja o tym, gdzie ani u kogo się ukrywał. 0 nim jednak mówił w rozmowie z Barbarą Engelking:

${ }^{19}$ Tomasz Siewierski, Janusz Durko (1915-2017). In Memoriam, „Almanach Warszawy” 2017 , t. 11 , s. 448-449.

${ }^{20}$ Rozmowa z Januszem Durko z kolekcji historii mówionej Muzeum Historii Żydów Polskich Polin, 2009 r. 
Mój brat został zadenuncjowany i wydany gestapo przez swojego kolegę szkolnego, którego spotkał na ulicy. Ten mu powiedział: „Jak się cieszę, że żyjesz, chodź, pójdziemy na piwo" - poszedł do toalety i wrócił z żandarmem. Mój brat został aresztowany, wzięto go na Pawiak. Zdążył tylko posłać gryps do mojej siostry i powiedzieć, kto to jest. Myśmy tego człowieka szukali po wojnie, ale on się gdzieś ukrył ${ }^{21}$.

W nieautoryzowanej wersji rozmowy, opublikowanej na łamach „Zagłady Żydów”, na pytanie: „Gdyby Pan znalazł tego chłopaka, który wydał brata...?”. Tych odpowiedział krótko: „To bym go osobiście zabił”22. W wersji autoryzowanej złagodził już swoją odpowiedź. Niemniej trudno wątpić w szczerość tej pierwszej reakcji.

\section{Wanda}

W pozostawionych przez Feliksa Tycha materiałach zachowała się teczka z dyplomem honorowym zaświadczającym o odznaczeniu Wandy Koszutskiej medalem Sprawiedliwej wśród Narodów Świata. Dodać należy, że odznaczenie to po wielu latach namów i próśb ze strony Feliksa i rodziny zgodziła się przyjąć na kilka miesięcy przed śmiercią.

Długo nie mogłem mojej przybranej matki namówić, by zgodziła się przyjąć medal i dyplom Yad Vashem dla Sprawiedliwych. Uważała, że zrobiła tylko to, co powinien był zrobić każdy przyzwoity człowiek. Ambasadorowi Państwa Izrael, gdy wręczał jej przed laty ten dyplom, powiedziała to samo ${ }^{23}$

- wspominał Feliks Tych w Bundestagu. We wspomnianej teczce zachowała się także kartka papieru, na której częściowo na komputerze, a częściowo ręcznie Feliks Tych pisał (nie jest to tekst skończony) swoje przemówienie z okazji wręczenia Wandzie medalu. Sądząc po zgięciach, miał ją wówczas złożoną w wewnętrznej kieszeni marynarki. Z relacji obecnej na uroczystości żony wiadomo, że tego przemówienia nie wygłosił. Zaczął, wzruszenie nie pozwoliło mu jednak kontynuować. Zamierzał powiedzieć m.in.: „[...] Wraz z szansą na przeżycie otrzymałem dom, drugą rodzinę. Gdybym miał określić jednym zdaniem, co tu było najważniejsze, to bym chyba powiedział, że stworzono mi takie warunki psychiczne, że się nie bałem. Bałem się o los swoich bliskich, modliłem się o ich życie, ale nie bałem się o siebie. Nie dlatego, że zagwarantowano mi 100-procentowe bezpieczeństwo. Takich gwarancji nie miał nikt. [...] Na to każdy ukrywający się Żyd, a także znaczna część Polaków musiała być przygotowana. [...] Każdy dzień życia był w jakimś sensie darowany i miałem pełną tego świadomość. Ale

${ }^{21}$ O ukrywaniu się po „aryjskiej stronie”. Z profesorem Feliksem Tychem rozmawia Barbara Engelking, „Zagłada Żydów. Studia i Materiały” 2005, nr 1, s. 236.

${ }^{22}$ Ibidem, s. 238.

${ }^{23}$ Bagaż [Rozmowa z Lucyną Berman-Tych]..., s. 246. 
się nigdy nie bałem. Może był to jakiś niedowład uczuć. Ale myślę, że raczej było to co innego: że była to zasługa Wandy, atmosfery, jaką stwarzała. Atmosfery codzienności, normalności. Można było mieć najlepszy a ryjski wygląd i zginąć przez strach w oczach. Przez zalęknienie. Ja go nigdy nie miałem i za to jej tak samo dziękuję, jak za ocalenie $[. . .]^{\prime 24}$. Przytoczony fragment zdaje się mówić więcej niż wszelkie inne wspomnienia o życiu i przeżyciu Tycha w okresie między opuszczeniem radomszczańskiego getta a końcem wojny.

Wanda Koszutska już przed wojną uczestniczyła w młodzieżowych organizacjach sympatyzujących z Komunistyczną Partią Polski, takich jak Związek Niezależnej Młodzieży Socjalistycznej „Życie”, w 1942 r. wstąpiła w szeregi Polskiej Partii Robotni-

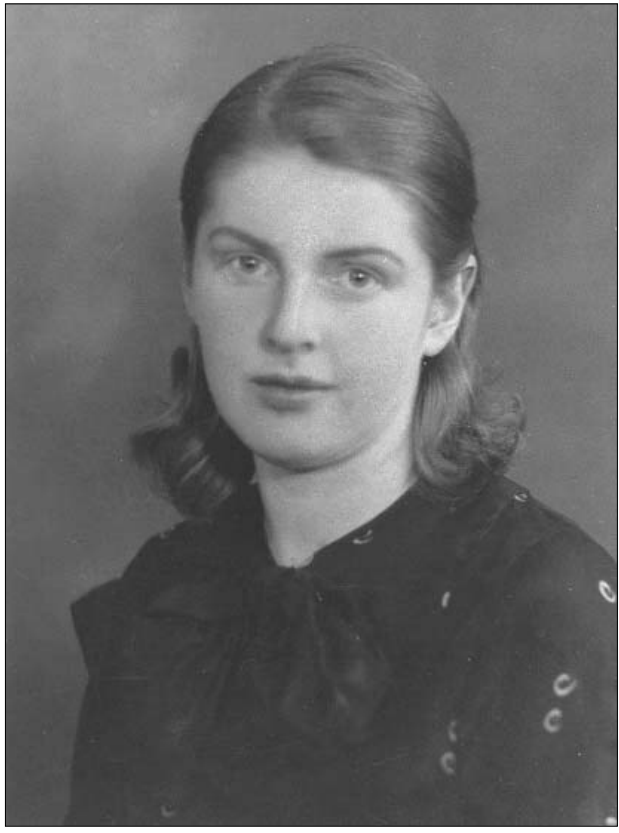

Wanda Koszutska (1909-2000, fot. ze zbiorów rodzinnych) czej $^{25}$. Wychowywała dwoje własnych dzieci (była w związku z działaczem PPS Feliksem Baranowskim), Feliks zaś był jednym z dwojga żydowskich dzieci, którymi się opiekowała ${ }^{26}$. Krąg towarzyski, relacje rodzinne, osobowość Wandy i jej intelektualny profil na pewno zbliżyły Tycha do ruchu lewicowego, wówczas w istocie komunistycznego. Jak wspomniałem wyżej, Fiszel wychowywał się w tradycyjnej rodzinie żydowskiej, a więc także religijnej. Tragedia wojenna sprawiła, że od religii odszedł i jak wspominała jego żona: „miejsce wiary zajął wpływ rodziny Koszutskich. On wiedział, że ci ludzie z Żoliborza to są szlachetni Polacy, i że chce być taki jak oni"27.

\footnotetext{
${ }^{24}$ Materiały w posiadaniu rodziny; kopia w zbiorach autora.

${ }^{25}$ Archiwum Akt Nowych (dalej AAN), Teczki osobowe działaczy polskiego ruchu robotniczego, Akta Wandy Koszutskiej, sygn. 12019.

${ }^{26}$ Bagaż [Rozmowa z Lucyną Berman-Tych]..., s. 245.

${ }^{27}$ Tychowa, Romanowski, Tak, jestem córką..., s. 92.
} 


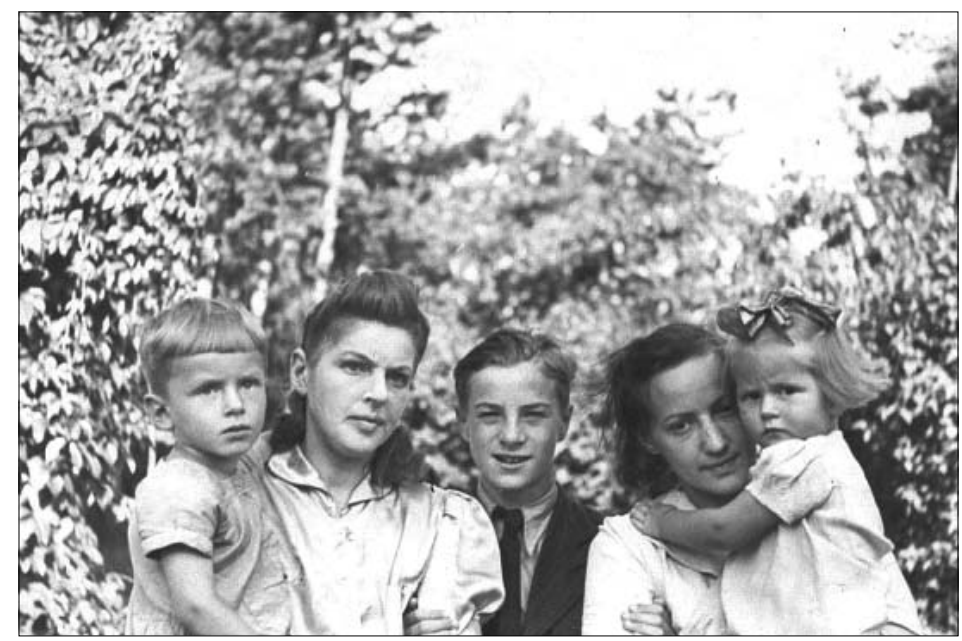

Jacek Baranowski (synek Wandy), Wanda Koszutska, Feliks Tych, Jadwiga Koszutska-Issat, Ewa Baranowska (córka Wandy, fot. ze zbiorów rodzinnych)

\section{Po wojnie...}

Jesienią 1944 r. Wanda Koszutska wraz z dziećmi udała się do Lublina, gdzie urzędował Polski Komitet Wyzwolenia Narodowego. Celem wyjazdu było spotkanie z siostrą Haliną Koszutską, potem znaną pisarką literatury dziecięcej i redaktorką „Przyjaciółki”, która wojnę spędziła w Związku Sowieckim. Halina miała córkę, rówieśnicę Feliksa, Olenę (późniejszą reżyser teatralną i telewizyjną, po mężu Listkiewicz). Opiekowała się także pasierbicą Władysława Broniewskiego Mają (późniejszą aktorką Marią Broniewską-Pijanowską) oraz Włodzimierzem Charszewskim, którego matka Zofia, znana pisarka literatury dziecięcej i młodzieżowej, zginęła w czasie pierwszego bombardowania Lwowa na początku wojny niemiecko-radzieckiej 22 czerwca $1941 \mathrm{r}^{28} \mathrm{~W}$ tym kręgu młodzieży znajdowała się także Lucyna Bermanówna, córka Jakuba. I tak w Lublinie zawiązały się przyjaźnie, które przetrwały przez kolejne dziesięciolecia. Między Feliksem a Lucyną przyjaźń trwała kilka lat, zanim przerodziła się w związek. Pobrali się w 1952 r., a do tego czasu ich losy przeplotły się kilkakrotnie ${ }^{29}$. Wyprzedzając nieco chronologię, warto dodać, że kiedy młodzi zawierali związek małżeński, ojciec Lucyny

${ }^{28}$ Maria Broniewska-Pijanowska, 44739. Wspomnienie o Marii Zarębińskiej - aktorce, Toruń: Wydawnictwo Adam Marszałek, 2016, s. 32.

${ }^{29}$ Rozmowa autora z Lucyną Berman-Tych. 


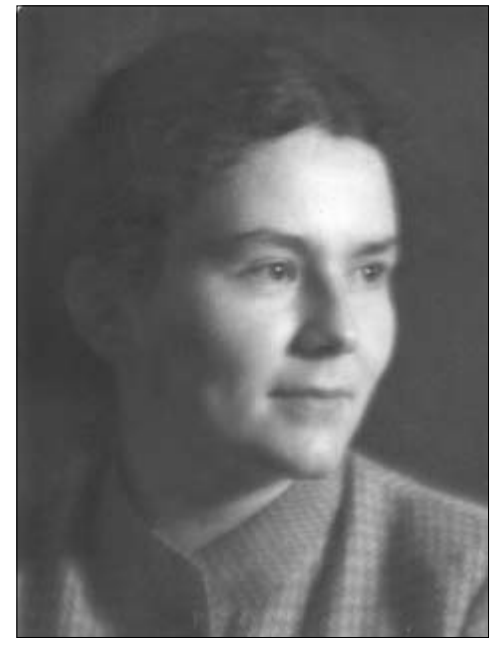

Lucyna Berman-Tych (1929-2019, fot. ze zbiorów rodzinnych)

był jednym z najbardziej wpływowych ludzi $\mathrm{w}$ państwie ${ }^{30}$. Rządy Bolesława Bieruta nierzadko określa się jako triumwirat, w którym dzielił on władzę między Bermana, Hilarego Minca i siebie. W istocie Bermanowi podlegały sprawy kultury oraz nadzór nad organami bezpieczeństwa. Ich działalność w okresie stalinowskim polegała m.in. na eliminacji - także fizycznej - przedstawicieli poakowskiego podziemia. Od 1956 r. Berman znajdował się poza partią, nie pełnił żadnych funkcji politycznych, a jednak nie tracił popularności, przy czym nie była to dobra sława. Nazwisko „towarzysza Jakuba" było na ogół wymieniane na początku litanii, która egzemplifikowała i miała uzasadniać prawdziwość mitu o „żydokomunie”. Jak zauważa Jaff Schatz: „Społeczna waga grupy czołowych polityków pochodzenia żydowskiego ostro kontrastowała z przypisywanym tradycyjnie Żydom niskim statusem. Typowym symbolem tego był stereotyp zbudowany na obecności w najwyższych władzach partyjno-państwowych trzech komunistów pochodzenia żydowskiego, wyrażający przekonanie, że «nami», to znaczy Polakami, rządzą «oni», to znaczy Żydzi; używanie ich nazwisk w liczbie mnogiej - «Bermanowie, Mincowie, Zambrowscy» - weszło na stałe do języka antysemityzmu" ${ }^{1}$. Łatka „zięcia Bermana” automatycznie przeniosła tę antysemicką kliszę na wiele formułowanych pod jego adresem ocen, zarówno wtedy gdy za rządów Jakuba Bermana kończył studia, jak i w czasach, gdy pełnił funkcję dyrektora ŻIH. Bycie córką i zięciem Jakuba Bermana miało istotne konsekwencje, które zaważyły na całym życiu Tychów. Dwudziestoletni Feliks Tych się tego obawiał. Z relacji jego żony złożonej autorowi tego artykułu wiadomo, że z pewną nieufnością odnosił się do działalności publicznej przyszłego teścia. Obawiał się w jakimś stopniu sytuacji, w której będzie widziany przez kolegów i współpracowników jako „zięć Bermana”. Chciał uniknąć podejrzeń o karierowiczostwo ${ }^{32}$.

${ }^{30}$ Więcej o politycznej karierze Jakuba Bermana zob. m.in. Anna Sobór-Świderska, Jakub Berman. Biografia komunisty, Warszawa: IPN, 2009; Robert Spałek, Na licencji Moskwy. Wokót Gomułki, Bermana i innych (1943-1970), Warszawa: IPN, 2020; Tychowa, Romanowski, Tak, jestem córką...

${ }^{31}$ Jaff Schatz, Pokolenie. Wzlot i upadek polskich Żydów komunistów, tłum. Sergiusz Kowalski, Warszawa: Ż̇H, 2020, s. 249-250.

${ }^{32}$ Rozmowa autora z Lucyną Berman-Tych. 


\section{Pożegnanie z Radomskiem}

W 1945 r. rodzina Koszutskich przeniosła się do Łodzi, która w odróżnieniu od Warszawy w miarę niezłym stanie przetrwała wojnę. Tutaj też w połowie maja 1945 r. ocalałe rodzeństwo odnalazło najmłodszego brata. Rena i Józef wiedzieli, gdzie go szukać. Przyjechali do Łodzi razem z Pinkusem, który wrócił ze Związku Radzieckiego, i we czwórkę pojechali do domu w Radomsku. Ich mieszkanie pozostawało niezamieszkane. Kilka dni po przybyciu odnalazła ich tam Halina (do 1942 Róża), która przyjechała z Jugosławii. Wspólnie zastanawiali się, co dalej robić. Większość rodzeństwa zdecydowana była na wyjazd z Polski. 0 powodach emigracji Reny Feliks Tych opowiedział w rozmowie z Barbarą Engelking:

W ostatnim okresie - szantażyści jej deptali po piętach - mieszkała w kolonii domków urzędniczych na Kleczewskiej, na Bielanach. [...] Przyjaźniła się z jakąś sąsiadką i w czasie powstania warszawskiego patrzyły na płonącą Warszawę, i siostra w rozmowie wyraziła żal, że miasto płonie. Sąsiadka jej na to odpowiedziała: „Wiesz co, oczywiście, że mi szkoda miasta, ale jak myślę, że w tych pożarach zginą Żydzi, co się jak pluskwy ukrywają w Warszawie, to mi nie żal". I siostra wtedy postanowiła, że jak wojna się skończy, to wyjedzie z Polski ${ }^{33}$.

Ostatecznie z rodziną osiadła w Kanadzie. Pinkus wyjechał do Monachium, a w końcu do Izraela. Jako jedyny został przy rodowym nazwisku. Józef początkowo pozostał w Warszawie, w 1968 r. wyjechał do Kanady. Halina wróciła do Jugosławii, gdzie zdążyła już założyć rodzinę. Feliks się wahał. Przy kraju trzymało go poczucie więzi rodzinnych z Wandą Koszutską oraz zadzierzgnięte w Lublinie, a z powodzeniem kontynuowane w Łodzi, przyjaźnie. Rodzeństwo namawiało go na wyjazd w poczuciu odpowiedzialności za najmłodszego brata. Jednak w dniach, gdy należało podjąć decyzję, Feliks złamał nogę. Złożono mu ją i unieruchomiono w gipsie. W tym stanie nie nadawał się do dalekiej podróży. W tych samych dniach w Radomsku rozeszła się wiadomość, że w położonym ok. $30 \mathrm{~km}$ od miasta Przeborzu zamordowano grupę miejscowych Żydów ${ }^{34}$. Wkrótce potem $\mathrm{w}$ drzwiach swojego mieszkania rodzeństwo znalazło liścik mówiący ni mniej ni więcej: „zniknijcie, bo też was to spotka”. Feliks wrócił do Łodzi. Z częścią rodzeństwa rozstał się na długie lata. Ta rozłąka, ale też miejsce i okoliczności przypieczętowały nowy rozdział w życiu Tycha.

${ }^{33}$ O ukrywaniu się po „aryjskiej stronie”. Z profesorem Feliksem Tychem rozmawia Barbara Engelking..., s. 237.

${ }^{34}$ Prawdopodobnie chodziło o zbrodnię opisaną przez Joannę Tokarską-Bakir w: Terror w Przedborzu, noc z 26/27 maja 1945 [w:] Bracia miesiqce. Studia z antropologii historycznej 1939-1945, Warszawa: Wydawnictwo IBL PAN, 2021; artykuł dostępny także w serwisie Academia.edu (dostęp 9 V 2021 r.). 


\section{Wybory zawodowe i wybory ideowe}

W Łodzi Feliks Tych ukończył Gimnazjum i Liceum Męskie im. T. Kościuszki i w 1948 r. zdał maturę. Trzeba dodać, że z domu rodziny Koszutskich wyniósł lewicowe ideały. Trudno przypuszczać, by przekładały się one na znajomość doktryny i lektury klasyków myśli marksistowskiej. Był to raczej świat wartości, które chłonął jako nastolatek. Niestety, nie dysponujemy źródłami wskazującymi, jak głębokie były to przekonania. W jednym ze wspomnień pisał: „Jako 13-14-letni chłopiec wychowałem się w środowisku PPR-owskim. Na pewno idee wpojone mi przez ludzi, których podziwiałem i kochałem, odegrały ogromną rolę $\mathrm{w}$ formowaniu mojego światopoglądu, ale bynajmniej nie odbywało się to automatycznie, nie działo się tylko i po prostu na zasadzie osmozy"35. Już w grudniu 1944 r. w Lublinie wstąpił do Związku Walki Młodych. O swoich doświadczeniach i zaangażowaniu politycznym w ZWM w czasach szkolnych opowiedział podczas rejestrowanej dyskusji w 1968 r. z okazji 50-lecia szkoły ${ }^{36}$. Na marginesie warto też dodać, że jako licealista był komendantem Młodzieżowej Brygady Traktorowej ZWM/ZMP w $1948 \mathrm{r}^{37}$

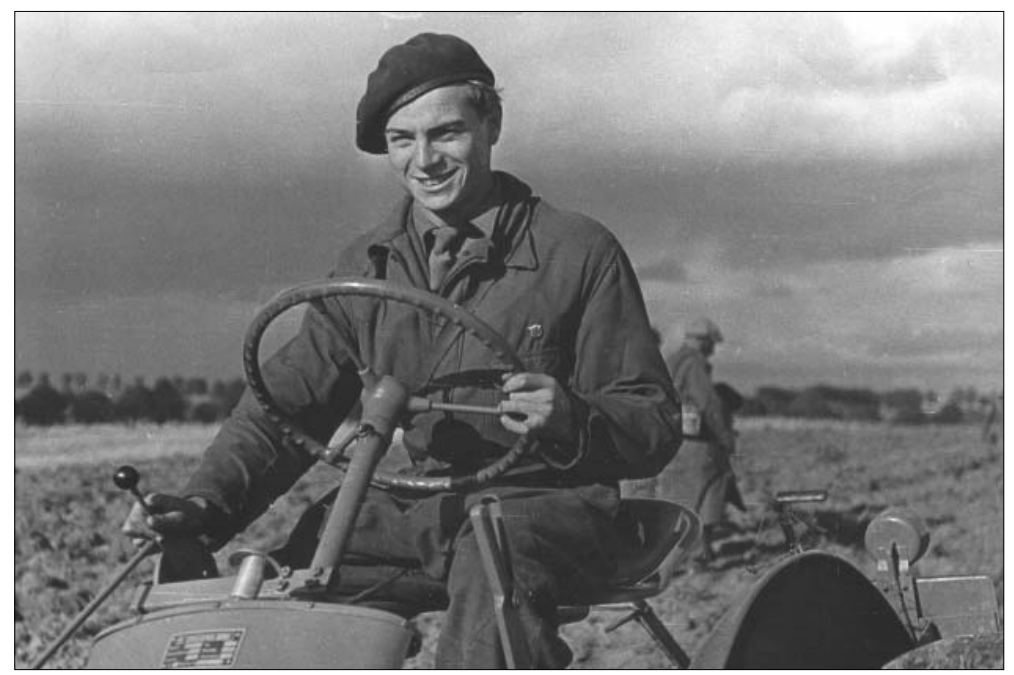

Feliks Tych jako komendant Młodzieżowej Brygady Traktorowej, 1948 r. (fot. ze zbiorów rodzinnych)

${ }^{35}$ Feliks Tych, Rewolucyjna mniejszość [w:] Wspomnienia ZWM-owców, red. Jan Gogacz, Warszawa: Iskry 1979, s. 310.

${ }^{36}$ Zob. W poszukiwaniu nowych dróg. Dyskusja przy magnetofonie, w której udział wzięli wychowankowie z pierwszych lat Polski Ludowej (1945-1949): Włodzimierz Charszewski, Jerzy Jedlicki, Adam Józefowicz, Tadeusz Kaczmarek, Włodzimierz Natorf, Maciej Perczyński, Feliks Tych, Bogdan Woleński [w:] Dzieje szkoły. 50-lecie Gimnazjum Miejskiego w Łodzi, red. Władysław Bieńkowski, Warszawa: Państwowe Zakłady Wydawnictw Szkolnych, 1968, s. 203-223.

${ }^{37}$ AAN, Centralne Archiwum KC PZPR, Teczka personalna Feliksa Tycha, sygn. XXIII-564. 
W 1948 r. Feliks Tych wstąpił na Wydział Historyczny Uniwersytetu Warszawskiego, gdzie od roku studiowała już jego przyszła żona Lucyna. I tu pojawia się odpowiedź na pytanie, w jaki sposób bardzo młody adept historii został pracownikiem centralnego aparatu partyjnego. Otóż w 1948 r. kierownik Wydziału Historii Partii KC PPR Tadeusz Daniszewski zaproponował Lucynie Tychowej pracę na pół etatu. Ta nie była ofertą zainteresowana, ale poleciła kontakt z Feliksem (od 1948 członkiem PPR), który akurat zaczynał studia, a ponieważ pozostawał na utrzymaniu Wandy Koszutskiej, możliwość zarobkowania była dla niego bardzo ważna ${ }^{38}$.

W 1948 r. Feliks Tych rozpoczął studia w Instytucie Historycznym Uniwersytetu Warszawskiego. Uczęszczał na seminarium poświęcone historii ruchu robotniczego, które prowadziła Żanna Kormanowa. Pod jej kierunkiem napisał pracę magisterską na temat Związku Robotników Polskich obronioną w 1951 r. $^{39}$ Przeredagowana i skrócona wersja tej pracy była drukowana w „Kwartalniku Historycznym" ${ }^{40}$. Po latach opublikował obszerne studium na ten sam temat ${ }^{41}$.

\section{Moskiewska aspirantura}

Po ukończeniu studiów magisterskich Feliks Tych wyjechał na studia doktoranckie (które wówczas na wzór sowiecki określano „aspiranturą”) do Moskwy ${ }^{42}$. Na Uniwersytecie Łomonosowa przygotowywał pracę pt. „SDKPiL w rewolucji 1905-1907". Promotorką dysertacji była Irina Bielawska. W późniejszych latach Tych poświęcił jej wspomnienie, w którym podkreślał jej polskie pochodzenie (nazwisko rodowe Tyszkiewicz) oraz zamiłowanie do polskiej kultury i historii, które wpajała studentom ${ }^{43}$. Postacią niesłychanie ważną, wpływową wówczas, z którą zetknął się w czasie studiów w Moskwie, była Anna Pankratowa związana z Akademią Nauk ZSRS. Od niej uzyskał zgodę na korzystanie z prohibitów i cimeliów z zasobów Rosyjskiej Biblioteki Państwowej (tzw. leninowskiej), dzięki czemu zapoznawał się z twórczością zakazanych wtedy zarówno w ZSRS, jak i Polsce ideologów myśli komunistycznej w oryginałach ${ }^{44}$. Pobyt w Moskwie był doświadczeniem z pewnością bardzo ważnym. W artykule do księgi dedy-

${ }^{38}$ Tychowa, Romanowski, Tak, jestem córkq̨..., s. 94.

${ }^{39}$ AUW, Akta studenckie Feliksa Tycha, sygn. WHum. 13996.

${ }^{40}$ Zob. Feliks Tych, Z działalności Zwiq̨zku Robotników Polskich 1889-1892, „Kwartalnik Historyczny" 1953, nr 2.

${ }^{41}$ Feliks Tych, Zwiq̨zek Robotników Polskich 1889-1892. Anatomia wczesnej organizacji robotniczej, Warszawa: Książka i Wiedza, 1974.

${ }^{42}$ Szerzej o środowisku polskich studentów w Związku Sowieckim w okresie stalinowskim zob. Mirosław Golon, Młodzież polska na studiach cywilnych i wojskowych w ZSRR w okresie klasycznego stalinizmu (1950-1956/1957), „Polska 1944/45-1989. Studia i Materiały” 2006, t. 7, s. 61-121.

${ }^{43}$ Feliks Tych, Irina Bielawska, „Polityka” 1975, nr 22, s. 15.

${ }^{44}$ Rozmowa autora z Lucyną Berman-Tych. 
kowanej pamięci Iriny Bielawskiej pisał: „Mimo widocznego zelżenia atmosfery politycznej po śmierci Stalina i egzekucji Berii - warunki funkcjonowania polskich i innych zagranicznych studentów i aspirantów w Moskwie się nie zmieniły. Nadal nie wolno było zapuszczać się poza granice Moskwy, oprócz wyjazdów do kraju. Jednak i na nie potrzebna była wiza wyjazdowa sowieckiej milicji. Mieszkańcy Moskwy nadal bali się przyjmować cudzoziemców w swoich mieszkaniach" 45 . W Moskwie po raz pierwszy od zakończenia drugiej wojny światowej zetknął się z antysemityzmem zarówno oficjalnym, jak i ludowym. Wiązało się to z tzw. sprawą lekarzy kremlowskich, a więc czystką Stalina o charakterze antysemickim, wymierzoną w środowisko medykó $\mathrm{w}^{46}$. W okresie jej rozpętania nie tylko obserwował sytuację dzięki lekturze gazet, lecz także jej doświadczał. Gdy z objawami grypy udał się do przychodni, usiadł w poczekalni do lekarza, do którego nie czekali inni pacjenci. „Życzliwa” pracownica lecznicy wróciła mu uwagę: „Dlaczego czeka pan do tego lekarza? Nie widzi pan, że nie ma kolejki? To Żyd, otruje pana". Było to jedno z tych doświadczeń, które odnowiło jego wojenną traumę ${ }^{47}$.

Obronionej dysertacji nigdy nie opublikował w całości, ale praca nad dziejami SDKPiL stanowiła początek jego zainteresowań biografią Róży Luksemburg.

\section{Rozwój kariery naukowej}

W 1955 r. wrócił do Warszawy, gdzie czekali na niego żona Lucyna oraz roczny syn Włodzimierz. W stolicy kontynuował pracę w Wydziale Historii Partii, który w 1957 r. przekształcono w Zakład Historii Partii przy KC PZPR. Od 1956 r. był także pracownikiem Instytutu Historii PAN. Tutaj pracował też jego starszy przyjaciel, najbliższy współpracownik Stanisław Kalabiński, z którym wspólnie napisali kilka prac ${ }^{48}$. Szczególnie ważnym rezultatem współpracy z Kalabińskim była wydana po raz pierwszy w 1969 r., później wznawiana, książka Czwarte powstanie czy pierwsza rewolucja poświęcona wydarzeniom rozgrywającym się między 1905 a 1907 r. na ziemiach Królestwa Polskiego. Feliks Tych był badaczem dziejów lewicy socjalistycznej. W 1959 r. habilitował się na podstawie

${ }^{45}$ Feliks Tych, Irina Michajłowna [w:] Profiessor MGU I.M. Bielawskaja. Matieriały konfieriencyi, poswiaszczennoj 90-letiju so dnia rożdienija profiessora MGU im. M.W. Łomonosowa I.M. Bielawskoj, Moskwa, 2005, s. 378-379.

${ }^{46}$ Zob. m.in. Jakow Rapoport, Ostatnia zbrodnia Stalina: 1953 - spisek lekarzy kremlowskich, tłum. Dorota Wieczorek, Warszawa: Instytut Wydawniczy Erica, 2011.

${ }^{47}$ Rozmowa autora z Lucyną Berman-Tych.

${ }^{48}$ Stanisław Kalabiński, Feliks Tych, Chłopi polscy w rewolucji 1905 r., Warszawa: Wiedza Powszechna, 1956; Walki chłopów Królestwa Polskiego w rewolucji 1905-1907, t. 1-4, oprac. Stanisław Kalabiński, Feliks Tych, Warszawa: PWN, 1958-1961; Stanisław Kalabiński, Feliks Tych, Czwarte powstanie czy pierwsza rewolucja: lata 1905-1907 na ziemiach polskich, Warszawa: Wiedza Powszechna, 1969. 
rozprawy PPS-Lewica w latach wojny 1914-1918 ${ }^{49}$. Rozprawa ukazała się drukiem rok później ${ }^{50}$. Z inicjatywy Feliksa Tycha od 1968 r. wydawano pierwszy po wojnie naukowy periodyk podejmujący zagadnienia historii polskiego ruchu robotniczego „Z Pola Walki”. Kwartalnik regularnie ukazywał się do 1989 r., Tych jednak musiał rozstać się z redakcją na skutek marcowej czystki w ZHP w roku 1970. Trzeba dodać, że czasopismo było bardzo ważnym osiągnięciem naukowym Feliksa Tycha. Pewnym paradoksem historiografii PRL jest to, że „Z Pola Walki" cieszyło się uznaniem nie tylko w kraju, lecz także wśród emigrantów politycznych. Pozytywnie oceniała je m.in. Lidia Ciołkoszowa ${ }^{51}$.

\section{Długi rok 1968}

Wydarzenia marcowe miały też więcej konsekwencji dla całej rodziny Feliksa Tycha niż tylko odebranie mu czasopisma. Przede wszystkim było to dość brutalne przypomnienie o jego pochodzeniu, co biorąc pod uwagę jego milczenie na temat rodziców i życia sprzed 1942 r., okazało się szczególnie bolesne. Trzeba także powiedzieć, choćby na podstawie materiałów Służby Bezpieczeństwa, że z moczarowskim antysemityzmem Tych stykał się przez kilka lat przed Marcem, ale w Marcu '68 gwałtownie wzrosło jego natężenie. Na początku lat sześćdziesiątych postrzegany już był jako „zięć Bermana” i ten cień towarzyszył zarówno jemu, jak i jego przyjaciołom, których - zdarzało się - przełożeni przesłuchiwali na okoliczność niesłusznych kontaktów. Tak było w przypadku lubelskiego historyka Zygmunta Mańkowskiego, który po spotkaniu w domu Tychów był wzywany w tej sprawie przez oficera SB poinformowanego za sprawą rektora $\mathrm{UMCS}^{52}$. W latach sześćdziesiątych Feliks Tych stał się obiektem zainteresowania i obserwacji SB. Świadczy o tym donos napisany przez jego kolegę Zygmunta Kolankowskiego, który w 1965 r. portretował Tycha jako „zięcia Bermana”, podkreślał jego materialny status, ale jako historyka przedstawiał go w samych superlatywach ${ }^{53}$. Zainteresowanie SB nasiliło się w 1967 r. Stało się tak w związku z donosem, że w czasie wojny sześciodniowej Tych zajął „stanowisko proizraelskie". W konsekwencji Lucynie i Feliksowi Tychom zastrzeżono wyjazdy zagraniczne, uzasadniając to „prowadzeniem działalności antysocjalistycznej z pozycji rewizjonistycznej i syjonistycznej”54. Niedługo później egzekutywa

\footnotetext{
${ }^{49}$ AAN, Centralne Archiwum KC PZPR, Teczka personalna Feliksa Tycha, sygn. XXIII-564.

${ }^{50}$ Zob. Feliks Tych, PPS-Lewica w latach wojny 1914-1918, Warszawa: Książka i Wiedza, 1960.

${ }^{51}$ Rozmowa autora z Lucyną Berman-Tych.

${ }^{52}$ Archiwum Instytutu Pamięci Narodowej w Lublinie, 09/478, Teczka podręczno-zagadnieniowa krypt. „Mątwy”, t. 2, k. 140-142.

${ }^{53}$ Alicja Kulecka, Tadeusz P. Rutkowski, Oczami agenta. Środowiska naukowe i archiwalne w doniesieniach TW „Zyg” - Zygmunta Kolankowskiego, Warszawa: Wydawnictwo Neriton, 2012, s. 408-409.

${ }^{54}$ Archiwum Instytutu Pamięci Narodowej, 0128/1028, [Materiały SB dotyczące Feliksa Tycha], k. 27-28.
} 
POP w ZHP zarzuciła mu kontakty zagraniczne i udostępnianie materiałów archiwalnych brytyjskiemu historykowi ${ }^{55}$. Ponadto marcowe doświadczenia Tychów były podobne do doświadczeń innych polskich Żydów: anonimowe obelżywe listy, głuche telefony, wizyty „życzliwych” sąsiadów z pytaniem, kiedy opuszczą mieszanie ${ }^{56}$. W kwietniu 1968 r. w murach Zakładu Historii Partii przy KC PZPR egzekutywa Podstawowej Organizacji Partyjnej zorganizowała trwającą 8 dni dyskusję, podczas której doprowadzono do dymisji dotychczasową dyrekcję ZHP: Tadeusza Daniszewskiego i Józefa Kowalskiego, „przypadkowo” mających żydowskie pochodzenie. Na czele egzekutywy stał Bronisław Syzdek. Zachował on w „prywatnym archiwum” ośmiusetstronicowe protokoły tych zebrań, dlatego jedynie z relacji świadków można ustalić, co tam się działo ${ }^{57}$. Janusz Durko, ówczesny zastępca kierownika ZHP, mówił: „To był amok! Amok, który doprowadził do tego, że to środowisko, których nazywam hunwejbinami, zaczęło robić czystkę, która objęła grupę pracowników Zakładu, którą stanowili Polacy żydowskiego pochodzenia. Główne uderzenie było zwrócone przeciw Daniszewskiemu i Kowalskiemu"58. Feliks Tych nie dzielił się z najbliższymi tym, co działo się w ZHP podczas narastania antysemickiej fali. Okres ten przypłacił długotrwałą bezsennością ${ }^{59}$. Trzydzieści lat po Marcu w wygłaszanym na rocznicowej konferencji naukowej referacie zauważał: „Słynne marcowe zebrania załóg czy organizacji partyjnych nie sprowadzały się tylko do reżyserowanych spektakli. Miały one w sobie sporo żywiołowych elementów, wiele z nastroju autentycznych wieców ludowych, co więcej, stwarzały pozór - tylko dlatego, że można było otwarcie manifestować antysemickie postawy i w tych ramach krytykować przedstawicieli władz partyjnych i państwowych - że oto rodzi się niemal wolność słowa ${ }^{60 "}$. W kontekście wydarzeń, jakie rozegrały się w murach Zakładu Historii Partii, trudno oprzeć się wrażeniu, że nie była to wyłącznie naukowa obserwacja Tycha. To było także jego osobiste doświadczenie.

\section{Po Marcu}

W 1968 r. zlikwidowano możliwość pracy na dwóch etatach i Feliks Tych zmuszony był odejść z pracy w Instytucie Historii PAN ${ }^{61}$. Zakład Historii Partii po marcowej czystce praktycznie przestał funkcjonować, w konsekwencji jako

\footnotetext{
${ }^{55}$ AAN, Zakład Historii Partii przy KC PZPR, Materiały Podstawowej Organizacji Partyjnej, sygn. XXII-745.

${ }^{56}$ Rozmowa z Lucyną Berman-Tych.

${ }^{57}$ Zrozumieć przeszłość. Z Bronisławem Syzdkiem o dziejach PRL i jego losach rozmawia Leon Wiarecki, Warszawa: Fundacja im. Kazimierza Kelles-Krauza, 1998, s. 76.

${ }^{58}$ Rozmowa z Januszem Durko, Warszawa, 20 IX 2013 r.

${ }^{59}$ Rozmowa z Lucyną Berman-Tych.

${ }^{60}$ Feliks Tych, Kilka uwag o marcu [w:] Marzec 1968. Trzydzieści lat później, t. 1: Referaty, red. Marcin Kula, Piotr Osęka, Marcin Zaremba, Warszawa: PWN, 1998, s. 19-20.

${ }^{61}$ Tychowa, Romanowski, Tak, jestem córkq̨..., s. 191.
} 
osobną instytucję wyodrębniono Centralne Archiwum KC PZPR. Pracował tam do emerytury w 1987 r. i kontynuował pracę badawczą. Koncentrował się głównie na dziejach ruchów socjaldemokratycznych ${ }^{62}$. Wraz z Aleksandrem Kochańskim zorganizowali redakcję „Archiwum Ruchu Robotniczego", periodyku, na którego łamach drukowano materiały źródłowe. Ważnym, jeśli nie najważniejszym, jego osiągnięciem była publikacja trzech tomów Słownika biograficznego działaczy polskiego ruchu robotniczego ${ }^{63}$, którego był inicjatorem i redaktorem naczelnym. W $1970 \mathrm{r}$. został profesorem nadzwyczajnym, lecz na uzwyczajnienie profesury musiał czekać dwanaście lat - do 1982 r. Na wcześniejszą emeryturę Feliks Tych przeszedł na skutek konfliktu z jego ówczesnym kierownikiem, Bronisławem Syzdkiem, tym samym, który kierował egzekutywą Podstawowej Organizacji Partyjnej w Zakładzie Historii Partii w marcu 1968 r.

W wieku 58 lat został bez odpowiedniego zajęcia. Bardzo owocne okazały się wówczas kontakty nawiązane podczas corocznych konferencji dotyczących historii ruchu robotniczego w Linzu. Pojawiły się oferty pracy dydaktycznej na uniwersytetach niemieckich. W 1990 r. otrzymał od Uniwersytetu w Getyndze propozycję objęcia rocznej profesury, którą sprawował w roku akademickim 1990/1991, a w semestrze zimowym 1992/1993 pełnił analogiczną funkcję na zaproszenie Wydziału Nauk Humanistycznych Technische Hochschule Darmstadt ${ }^{64}$. To było bardzo ważne doświadczenie, po pierwsze dlatego, że kariera naukowa Tycha nabrała wówczas w niemałym stopniu międzynarodowego charakteru. Ważny był także czynnik psychologiczny - praca dydaktyczna bardzo otworzyła go na młodych ludzi, co potem miało ogromne znaczenie, gdy w 1995 r. otrzymał propozycję kierowania Żydowskim Instytutem Historycznym.

\section{Dyrektor ŻIH}

Gdy Marian Turski przekazał mu propozycję objęcia stanowiska dyrektora ŻIH, trudno było kojarzyć Tycha ze środowiskiem badaczy historii Żydów, bo tą tematyką właściwie się nie zajmował. 0 tyle tylko, że te wątki przenikały wielokrotnie i na różnych płaszczyznach historię ruchu robotniczego, którą zgłębiał. Decyzja o przyjęciu tej funkcji była trudna, ale przeważył argument żony, która powiedziała: „jesteś to winien rodzicom" ${ }^{65}$. W ŻIH był głównie organizatorem, zaczął także podejmować tematykę żydowską w swoich pracach ${ }^{66}$. W tym kon-

${ }^{62}$ Zob. Feliks Tych, Socjalistyczna irredenta. Szkice z dziejów polskiego ruchu robotniczego pod zaborami, Kraków: Wydawnictwo Literackie, 1982.

${ }^{63}$ Słownik biograficzny działaczy polskiego ruchu robotniczego, red. nacz. Feliks Tych, t. 1-3, Warszawa: Muzeum Niepodległości w Warszawie oraz Książka i Wiedza, 1978-1992.

${ }^{64}$ Autobiografia naukowa Feliksa Tycha ze zbiorów rodzinnych; kopia w zbiorach autora.

${ }^{65}$ Rozmowa autora z Lucyną Berman-Tych.

${ }^{66}$ Zob. m.in. Feliks Tych, Długi cień zagłady. Szkice historyczne, Warszawa: ŻıH, 1999; Następstwa zagłady Żydów. Polska 1944-2010, red. Feliks Tych, Monika Adamczyk-Garbowska, Lublin: Wydawnictwo UMCS, 2012. 
tekście niesłychanie ważny stał się udział żony w jego życiu zawodowym. Dzięki świetnej znajomości literatury dotyczącej Holokaustu i nieprawdopodobnemu zrozumieniu, wyczuciu tej problematyki wynikającemu także z warsztatu historyczki, była dla niego wielkim wsparciem ${ }^{67}$. Jako dyrektor ŻIH Feliks Tych po raz pierwszy zetknął się z pracą organizacyjną na większą skalę. Musiał się zmierzyć $\mathrm{z}$ wieloma problemami, z których najbardziej palącym były kwestie finansowe. Działalność naukowa pracowników Żydowskiego Instytutu Historycznego kierowała się w większym zakresie w stronę dziejów Zagłady i jej konsekwencji. Jak zwraca uwagę Andrzej Żbikowski, była to tematyka ważna osobiście dla Feliksa Tycha ${ }^{68}$. Warto również podkreślić, że katalizatorem badań nad Holokaustem okazała się społeczna potrzeba, którą wywołały dyskusje wokół głośnej publikacji Jana Tomasza Grossa Sąsiedzi ${ }^{69}$. W publicznej debacie wokół jedwabieńskiej zbrodni Tych niejednokrotnie zabierał głos ${ }^{70}$. Koniecznym odnotowania jego dokonaniem jako dyrektora ŻIH jest wpisanie Archiwum Ringelbluma na listę „Pamięć Świata” UNESCO ${ }^{71}$. Tych inicjował także projekty edukacyjne mające na celu popularyzację dziejów Żydów polskich wśród młodzieży szkolnej. Na tym polu szczególnie owocna okazała się współpraca z Fundacją Shalom Gołdy Tencer. W 2004 r. Fundacja wydała popularnonaukową książkę pod redakcją Tycha Pamięć. Historia Żydów Polskich przed, w czasie, i po Zagładzie. Zespół autorski współtworzyli Barbara Engelking, Feliks Tych, Andrzej Żbikowski oraz Jolanta Żyndul. Jednym z ważniejszych osiągnięć Tycha jako organizatora badań nad historią Żydów polskich było zainicjowanie serii wydawniczej ŻIH pt. „Wspomnienia, Relacje, Dzienniki”. Pierwszym tomem okazał się pamiętnik Celiny Budzyńskiej ${ }^{72}$, której losy głęboko wpisują się w dzieje polskich komunistów, a jednocześnie obrazują zaangażowanie Żydów w ruchu lewicowym. Miał więc Feliks Tych poczucie wielkiej wartości, jaką stanowią świadectwa ocalałych od Zagłady Żydów. Jednocześnie odczuwał niemoc, która nie pozwalała mu na spisanie własnych wspomnień. Gdy taką próbę podjął, w następstwie „nie spał trzy tygodnie"73.

${ }^{67}$ Przykład ich wzajemnej współpracy stanowi artykuł: Lucyna i Feliks Tych, Getto warszawskie $w$ polskich dziennikach wojennych [w:] Żydzi Warszawy. Materiały konferencji $w$ Żydowskim Instytucie Historycznym $w$ 100. rocznicę urodzin Emanuela Ringelbluma, red. Eleonora Bergman, Olga Zienkiewicz, Warszawa: ŻIH, 2000, s. 229-240.

${ }^{68}$ Andrzej Żbikowski, Żydowski Instytut Historyczny. 70 lat badań nad dziejami polskich Żydów. Pisane z perspektywy historyka Zagłady, Warszawa: ŻıH, 2018, s. 99.

${ }^{69}$ Zob. Jan Tomasz Gross, Sąsiedzi. Historia zagłady żydowskiego miasteczka, Sejny: Pogranicze, 2000.

${ }^{70}$ Pamięć jako pole bitwy [dyskusja z udziałem Włodzimierza Borodzieja, Pawła Machcewicza, Grzegorza Motyki i Feliksa Tycha], „Przegląd Polityczny” 2021, nr 52/53, s. 9-20.

${ }^{71}$ Instytut. 70 lat historii ŻIH w dokumentach źródłowych, oprac. Helena Datner, Olga Pieńkowska, Warszawa: ŻIH, 2017, s. 201.

${ }^{72}$ Celina Budzyńska, Strzępy rodzinnej sagi, Warszawa: ŻIH, 1997.

${ }^{73}$ Tychowa, Romanowski, Tak, jestem córkq..., s. 191. 
Praca w ŻIH była jednak dla Feliksa Tycha czasem pewnego otwarcia czy może przełamania: dopiero wtedy zaczął wspominać cokolwiek więcej o swoim doświadczeniu, zwłaszcza o okresie życia po aryjskiej stronie w okupowanej Warszawie i Miedzeszynie. Jeszcze jako dyrektor Żydowskiego Instytutu Historycznego udzielił Barbarze Engelking wywiadu, który ukazał się w „Zagładzie Żydów"74. W 2000 r. wygłaszał laudację, będącą osobistym wspomnieniem dla Wandy Koszutskiej, która otrzymała medal Sprawiedliwej wśród Narodów Świata (jak już wspomniałem, wzruszenie nie pozwoliło mu odczytać całości). Trzecim i ostatnim autobiograficznym wystąpieniem było przemówienie w Bundestagu w 2010 r. w momencie, gdy ciężka choroba zaczęła dewastować jego pamięć. W tym wystąpieniu zawarł chyba jednak najwięcej wspomnień na temat swojego żydowskiego doświadczenia ${ }^{75}$.

„Niektórzy z ocalonych milczeli. Nie był w stanie mówić o tej przepaści, która nas dzieliła. On do nich należał, widocznie był za bardzo zraniony. To były rany, które chronił" - mówiła o mężu Lucyna Tych ${ }^{76}$.

Feliks Tych zmarł 17 lutego 2015 r. Został pochowany na Cmentarzu Żydowskim przy ul. Okopowej w Warszawie.

\section{BIBLIOGRAFIA}

\section{Źródła archiwalne}

\section{Archiwum Akt Nowych (AAN)}

Centralne Archiwum KC PZPR, Teczka personalna Feliksa Tycha, sygn. XXIII-564 Teczki osobowe działaczy polskiego ruchu robotniczego, Akta Wandy Koszutskiej, sygn. 12019

Zakład Historii Partii przy KC PZPR, Materiały Podstawowej Organizacji Partyjnej, sygn. XXII-745

\section{Archiwum Instytutu Pamięci Narodowej (AIPN)}

$09 / 478$

$0128 / 1028$

\section{Archiwum Uniwersytetu Warszawskiego (AUW)}

Akta studenckie Feliksa Tycha, sygn. WHum. 13996

\section{Zbiory prywatne}

Materiały rodziny Feliksa Tycha.

\section{Relacje}

Rozmowy autora z Lucyną Berman-Tych

Rozmowa autora z Januszem Durko

${ }^{74}$ O ukrywaniu się po „aryjskiej stronie”. Z profesorem Feliksem Tychem rozmawia Barbara Engelking, „Zagłada Żydów. Studia i Materiały” 2005, nr 1; Rozmowa z prof. Feliksem Tychem, „Zagłada Żydów. Studia i Materiały” 2006, nr 2.

${ }^{75}$ Speech by Professor Feliks Tych [w:] Day of Remembrance for the Victims of National Socialism. Ceremony of Remembrance at the German Bundestag on 27 January 2010, s. 64-69.

${ }^{76}$ Bagaż [Rozmowa z Lucyną Berman-Tych]..., s. 248. 
Rozmowa z Januszem Durko z kolekcji historii mówionej Muzeum Historii Żydów Polskich Polin

\section{Źródła publikowane}

Bagaż [Rozmowa z Lucyną Berman-Tych] [w:] Przynoszę rzecz, przynoszę historię. Rozmowy z darczyńcami, red. Judyta Pawlak, Przemysław Kaniecki, Warszawa: Muzeum Historii Żydów Polskich Polin, 2016.

Broniewska-Pijanowska Maria, 44739. Wspomnienie o Marii Zarębińskiej - aktorce, Toruń: Wydawnictwo Adam Marszałek, 2016.

Budzyńska Celina, Strzępy rodzinnej sagi, Warszawa: ŻIH, 1997.

Instytut 70 lat historii ŻIH $w$ dokumentach źródłowych, oprac. Helena Datner, Olga Pieńkowska, Warszawa: ŻIH, 2017.

Kulecka Alicja, Rutkowski Tadeusz P., Oczami agenta. Środowiska naukowe i archiwalne $w$ doniesieniach TW „Zyg”- Zygmunta Kolankowskiego, Warszawa: Wydawnictwo Neriton, 2012.

O ukrywaniu się po „aryjskiej stronie”. Z profesorem Feliksem Tychem rozmawia Barbara Engelking, „Zagłada Żydów. Studia i Materiały” 2005, nr 1.

Pamięć jako pole bitwy [dyskusja z udziałem Włodzimierza Borodzieja, Pawła Machcewicza, Grzegorza Motyki i Feliksa Tycha], „Przegląd Polityczny” 2021, nr 52/53.

Pamiętnik Miriam Chaszczewackiej, oprac. Feliks Tych, „Zagłada Żydów. Studia i Materiały" 2013, nr 9.

Rozmowa z prof. Feliksem Tychem, „Zagłada Żydów. Studia i Materiały” 2006, nr 2.

Speech by Professor Feliks Tych [w:] Day of Remembrance for the Victims of National Socialism. Ceremony of Remembrance at the German Bundestag on 27 January 2010.

Tych Feliks, Irina Bielawska, „Polityka” 1975, nr 22.

Tych Feliks, Irina Michajłowna [w:] Profiessor MGU I.M. Bielawskaja. Matieriały konfieriencyi, poswiaszczennoj 90-letiju so dnia rożdienija profiessora MGU im. M.W. Łomonosowa I.M. Bielawskoj, Moskwa 2005.

Tych Feliks, Rewolucyjna mniejszość [w:] Wspomnienia ZWM-owców, red. Jan Gogacz, Warszawa: Iskry, 1979.

Tych Feliks, Wstęp [w:] Folman-Raban Chawka, Nie rozstałam się z nimi, Warszawa: ŻIH, 2000.

Tychowa Lucyna, Romanowski Andrzej, Tak, jestem córką Jakuba Bermana, Kraków: Universitas, 2016.

W poszukiwaniu nowych dróg. Dyskusja przy magnetofonie, w której udział wzięli wychowankowie z pierwszych lat Polski Ludowej (1945-1949): Włodzimierz Charszewski, Jerzy Jedlicki, Adam Józefowicz, Tadeusz Kaczmarek, Włodzimierz Natorf, Maciej Perczyński, Feliks Tych, Bogdan Woleński [w:] Dzieje szkoły. 50-lecie Gimnazjum Miejskiego $w$ Łodzi, red. Władysław Bieńkowski, Warszawa: Państwowe Zakłady Wydawnictw Szkolnych, 1968.

Zrozumieć przeszłość. Z Bronisławem Syzdkiem o dziejach PRL i jego losach rozmawia Leon Wiarecki, Warszawa: Fundacja im. Kazimierza Kelles-Krauza, 1998.

\section{Literatura przedmiotu}

Golon Mirosław, Młodzież polska na studiach cywilnych i wojskowych $w$ ZSRR $w$ okresie klasycznego stalinizmu (1950-1956/1957), „Polska 1944/45-1989. Studia i Materiały" 2006, t. 7.

Gross Jan Tomasz, Sąsiedzi. Historia zagłady żydowskiego miasteczka, Sejny: Pogranicze, 2000. 
Kalabiński Stanisław, Tych Feliks, Chłopi polscy w rewolucji 1905 r., Warszawa: Wiedza Powszechna, 1956.

Stanisław Kalabiński, Tych Feliks, Czwarte powstanie czy pierwsza rewolucja: lata 19051907 na ziemiach polskich, Warszawa: Wiedza Powszechna, 1969.

Kancewicz Jan, Koszutski Bronisław Romuald [w:] Słownik biograficzny działaczy polskiego ruchu robotniczego, t. 3, red. nacz. Feliks. Tych, Warszawa: Muzeum Niepodległości w Warszawie oraz Książka i Wiedza, 1992.

Kendziorek Piotr, Feliks Tych - szkic biograficzny in memoriam, „Kwartalnik Historii Żydów" 2015, z. 3.

Koszutska-Issat Jadwiga Danuta [w:] Michał Grynberg, Księga sprawiedliwych, Warszawa: Wydawnictwo Naukowe PWN, 1993.

Landau-Czajka Anna, Feliks Tych (31 VII 1929 - 17 II 2015), „Kwartalnik Historyczny” 2016, z. 3.

Następstwa zagłady Żydów. Polska 1944-2010, red. Feliks Tych, Monika Adamczyk-Garbowska, Lublin: Wydawnictwo UMCS, 2012.

Rapoport Jakow, Ostatnia zbrodnia Stalina: 1953 - spisek lekarzy kremlowskich, tłum. Dorota Wieczorek, Warszawa: Instytut Wydawniczy Erica, 2011.

Schatz Jaff, Pokolenie. Wzlot i upadek polskich Żydów komunistów, tłum. Sergiusz Kowalski, Warszawa: ŻIH, 2020.

Siewierski Tomasz, Janusz Durko (1915-2017). In Memoriam, „Almanach Warszawy” 2017, t. 11.

Sobór-Świderska Anna, Jakub Berman. Biografia komunisty, Warszawa: IPN, 2009.

Spałek Robert, Na licencji Moskwy. Wokół Gomułki, Bermana i innych (1943-1970), Warszawa: IPN, 2020.

Tokarska-Bakir Joanna, Terror w Przedborzu, noc z 26/27 maja 1945 [w:] Bracia miesiace. Studia $z$ antropologii historycznej 1939-1945, Warszawa: Wydawnictwo IBL PAN, 2021, artykuł dostępny w serwisie Academia.edu.

Tych Feliks [w:] Kto jest kim w Polsce. Informator biograficzny, edycja 3, red. Lubomir Mackiewicz, Anna Żołna, Warszawa: Interpress, 1993.

Tych Feliks, Długi cień zagłady. Szkice historyczne, Warszawa: ŻıH, 1999.

Tych Feliks, Kilka uwag o marcu [w:] Marzec 1968. Trzydzieści lat później, t. 1: Referaty, red. Marcin. Kula, Piotr Osęka, Marcin. Zaremba, Warszawa: Wydawnictwo Naukowe PWN, 1998.

Tych Feliks, PPS-Lewica w latach wojny 1914-1918, Warszawa: Książka i Wiedza, 1960.

Tych Feliks, Socjalistyczna irredenta. Szkice z dziejów polskiego ruchu robotniczego pod zaborami, Kraków: Wydawnictwo Literackie, 1982.

Tych Feliks, Z działalności Związku Robotników Polskich 1889-1892, „Kwartalnik Historyczny" $1953, \mathrm{nr} 2$.

Tych Feliks, Zwiq̨zek Robotników Polskich 1889-1892: anatomia wczesnej organizacji robotniczej, Warszawa: Książka i Wiedza, 1974.

Tych Lucyna i Feliks, Getto warszawskie w polskich dziennikach wojennych [w:] Żydzi Warszawy. Materiały konferencji w Żydowskim Instytucie Historycznym w 100. rocznice urodzin Emanuela Ringelbluma, red. Eleonora Bergman, Olga Zienkiewicz, Warszawa: Ż̇H, 2000.

Walki chłopów Królestwa Polskiego w rewolucji 1905-1907, t. 1-4, oprac. Stanisław Kalabiński, Feliks Tych, Warszawa: PWN, 1958-1961.

Żbikowski Andrzej, Żydowski Instytut Historyczny. 70 lat badań nad dziejami polskich Żydów. Pisane z perspektywy historyka Zagłady, Warszawa: ŻIH, 2018. 